\title{
Histone H3 Methyl Lys4
}

National Cancer Institute

\section{Source}

National Cancer Institute. Histone H3 Methyl Lys4. NCl Thesaurus. Code C120024.

A form of histone $\mathrm{H} 3$ where the lysine residue at position 4 has been post-translationally modified with a single methyl group. This modification may be a marker for transcriptionally active genes. 